\title{
Academic Management Actions Facing Reforms in Curriculum and in Competencies Required to Graduating from an Accounting Sciences Course
}

\author{
Vilma Geni Slomski¹, Luciana Regina da Silva Souza1, Anísio Candido Pereira1, \\ Antonio Carlos Ribeiro da Silva ${ }^{2}$ \\ ${ }^{1}$ Álvares Penteado School of Commerce Foundation-FECAP, São Paulo, Brazil \\ ${ }^{2}$ Federal University of Bahia (UFBA), Salvador, Brazil \\ Email: vilma.geni@fecap.br
}

Received 8 March 2016; accepted 16 May 2016; published 19 May 2016

Copyright (C) 2016 by authors and Scientific Research Publishing Inc.

This work is licensed under the Creative Commons Attribution International License (CC BY). http://creativecommons.org/licenses/by/4.0/

(c) (i) Open Access

\begin{abstract}
This study aimed to assess academic management actions facing the set of professional competencies that graduates from an Accounting Sciences course need to graduate. To this end, we carried out a qualitative descriptive study. Data were collected through interviews and analyzed using content analysis. We found that the set of graduates' professional competencies concerning organizational, technical-professional and social spheres requires academic management actions such as: 1) democratic governance and collective development of a curricular pedagogical project; 2) establishment of places for interaction between fields/disciplines (structuring teaching core); 3) use of conflict management strategies; 4) activities that favor professional ethics; 5) activities that favor leadership, commitment and trust; 6) curriculum flexibility; 7) strategic planning and evaluation of actions; 8) professional self-development. Activities and mechanisms that encourage the participation of all those involved in decision-making characterize democratic management and academic management's leadership. We conclude that democratic-participative management may favor professionals' graduation processes in the contemporary world, and may be a way of ensuring the development of students' cognitive, operational, social and moral competencies, through their commitment to curriculum dynamics, to the development of thought and creation processes, to the establishment of participatory citizenship and to ethical education.
\end{abstract}

Keywords

Graduation Coordination, Professional Competencies, Accounting Education

How to cite this paper: Slomski, V. G., da Silva Souza, L. R., Pereira, A. C., \& da Silva, A. C. R. (2016). Academic Management Actions Facing Reforms in Curriculum and in Competencies Required to Graduating from an Accounting Sciences Course. Creative Education, 7, 910-921. http://dx.doi.org/10.4236/ce.2016.77095 


\section{Introduction}

The current production model brings with it new challenges and demands concerning the competencies of workers. According to Siqueira (2003: p. 7) "horizontal organization (as opposed to Fordist vertical organization), there emphasizes the shared responsibility of workers and increases the importance of communication in which knowledge can be communicated amongst workers and between workers and the company"; dedication to a single task is also replaced by carrying out multiple functions.

This means that the flexible production model is also a driver of change within working, consumption and technology processes, which go way beyond the companies that reach other segments of society, especially educational institutions, schools and universities. This scenario of change directly interferes with educational policies, especially in Brazil; with respect to the curriculum reforms that are underway, authors such as Souza (1998) note that the latter has become different political actions, in which the discussion concerning curriculum is the "flagship". However, it is noteworthy that universities are not limited to simply place to educate and train professionals for the labor market.

Thus, this study will use the term "world of work", since, as well as technical competency (knowing how to do), the formation of "professional-citizens" (Masetto, 2003) involves cognitive (knowing), attitudinal and ethical (knowing how to be) dimensions (Deffune \& Depresbiteris, 2002: pp. 19-75). Therefore, it is relevant to consider, in equal proportion, any research in teaching, and vice versa, within professional training.

To tune universities into the paradigms of the contemporary world and into the scientific and technological training of students, the Brazilian 1996 Guidelines and Framework Law \#9394 (Lei de Diretrizes e Bases-LDB Brazil Law \#9394, 1996) sought to lead undergraduate courses to comply through National Curricular Guidelines (Diretrizes Curriculares Nacionais-DCN). Curricular changes adopted for undergraduate courses were guided by the following principles: 1) flexibility in curricular organization; 2) curriculum dynamics; 3) adaptation to the demands of the labor market; 4) integration between undergraduate and graduate courses; 5) emphasis on general education, etc.

The Guidelines and Framework Law \#9394 supports the establishment of pedagogical proposals that emerge from an academic institution with a view to "shaping the identity and the particularities of the educational institution" (Veiga \& Fonseca, 2001: p. 187). It defends flexibility, autonomy and democratic and participatory management as to the historical-critical concept of socio-political education as opposed to the traditional scientific-rational concept; this is what differentiates current curriculum changes facing the challenges of the contemporary world (Libâneo, 2001).

The changes resulting from the 1996 LDB are an attempt to improve the quality of higher education by proposing the autonomy of Higher Education Institutions (HEIs) and establishing guidelines for the pedagogical projects of courses seeking curricular flexibility. With regard to the Accounting Sciences course, Brazil Resolution CNE/CES 10 (2004) proposes guidelines that are in line with the LDB and with what is proposed by international bodies such as the International Accounting Education Standards Board (IAESB), which issues the International Education Standards for Professional Accountants, and the International Federation of Accountants (IFAC, 2012), which highlights the need to adapt courses following the changes that have occurred in this profession.

In this same line of thought, Cosenza (2001) says that accountants must have more than technical training; accounting requires competencies that go way beyond the practical experience of meeting the basic objective of accounting, which, according to Iudicibus \& Marion (2000: p. 23), is "to provide financial information to users so as to facilitate rational decisions".

In this regard, authors such as Libâneo (2001); Libâneo et al. (2003); Veiga (2004); Gadotti \& Romão (2000); Bordignon \& Gracindo (2004) state that managers should be predisposed to performing decentralized and participatory management involving the academic community as a whole, facing the construction of the course Political Pedagogical Project (Projeto Político Pedagógico-PPP), in order to carry out shared work as to academic management - planning, organizing and thus evaluating the whole process of teaching and learning in view of achieving desired educational goals and objectives.

This study, the choice of subject and the formulation of the following research question were motivated by the desire to unveil the management style and actions of academic management facing the desired profile of course graduates: What academic management actions should be carried out facing the professional competencies required of students graduating from an Accounting Sciences course? 
Thus, we drew up as general objective getting to know what actions are carried out by academic management facing the set of professional competencies required of graduates from an Accounting Sciences course in the city of São Paulo, seeking thereby to identify which competencies are priorities to academic management facing the desired profile of course graduates.

We hope that this research will contribute to greater knowledge concerning academic management actions facing the set of professional competencies needed by graduates of undergraduate courses, and that it will offer subsidies for reflections by professionals who work as program coordinators, especially in accounting, so that their decision-making through curricular adaptations allow greater alignment between the world of work and the profession.

\section{Theoretical Foundations}

Considering that academic management is the focus of this study, in this session we will discuss concepts such as academic management, Political Pedagogical Project, professional competency and the set of competencies of accountants.

\subsection{The Academic Management Concept in the Context of Curriculum Reform in Brazil}

Higher education must urgently follow the process of socio-political and economic transformation that requires, among other demands, changes in the way management occurs (Barbalho, 2007). In this same line of thought, Masetto (2003) discusses the concept of higher education that permeates university management and the fact that the latter is understood as a system that trains professionals for the labor market. The author emphasizes the need for universities to assume their ethical and political function of training "professional-citizens".

Management is understood in this study in accordance with Libâneo (2001: p. 78), who claims that it is the "intentional and systematic process of reaching a decision and making this decision work"; the decision-making process occurs collectively, in a participatory way, as opposed to centralized and technocratic management, in which decisions are made from the top and are passed down, simply fulfilling a previously elaborated plan, without the participation of teachers, experts and others who are involved in school education.

The democratic concept of academic management helps universities to fulfill their function of measuring the quality of education they provide in the competency of the professionals they train (Slomski, 2007), which results in the "appropriation of knowledge, procedures, attitudes and values by students" (Libâneo, 2001: p. 111). In this context, the course Political Pedagogical Project (PPP) is presented as an academic management tool.

\section{The Course Political Pedagogical Project as a Management Tool}

Aiming to put into practice citizenship education for democratic and participatory management, the Law of Guidelines and Bases of National Education (Lei de Diretrizes e Bases da Educação Nacional-LDBEN, 9394/96) says in its Article 12 that: "Schools, in compliance with common standards and its teaching system, will have the task of: I-developing and implementing its pedagogical proposal". Thus, the PPP's role of politically and methodologically organizing the school environment and of being a participatory action mechanism in the field of management is recognized. Thus, the LDB 9394/96 seeks to overcome the LDB 4024/61 (minimum curriculum) based on the traditional paradigm of academic administration.

The Pedagogical Political Project (PPP) has been represented in official speech as a way to change the curriculum and reaching quality in higher education; in this sense André (2001: p. 188) warns that "the PPP is not just a letter of intentions, nor just comes down to an administrative requirement". It must necessarily "express the reflection and the work carried out jointly by all school personnel, in order to meet the guidelines of the national educational system, as well as the local and specific needs of the school clientele; in this way, it realizes the school's identity and offers guarantees of quality education".

As an organization and management mechanism, the PPP also means: "a theoretical and methodological tool which aims to help meet the challenges of everyday school life, but in a reflected, conscious, systematic, organic way, and, the most essential, in a participatory way." And a work methodology that allows "reframing of all the actions of the institution's agents" (Vasconcelos, 1995: p. 143). This means that the PPP's political dimension is in the project idea and in the intention of the teaching practice. Gadotti (2000: pp. 35-36), in this sense, says that "one does not build a project without political direction, a north, a direction. Therefore, every pedagogical project is also political." Namely, what idea does one have of education? What profile of graduate does one 
want from the course? To live in what society? The project idea always indicates an "ongoing process, one step toward a purpose that remains as a horizon" of the educational institution (Gadotti, 2000: pp. 35-36).

Addressing the PPP development challenge in part of managers' boldness, of the mechanisms and management tools that they will use for the construction and experience of the pedagogical program; in this sense, (Veiga, 1996: p. 14) suggests that theoretical and methodological foundations of the science and the pedagogy be used in the construction and implementation of the Project, so that the changes are significant and education is of good quality.

Gadotti (2000: p. 38) in turn highlights the competencies that must be a priority in order to optimize and qualify the pedagogical proposal as to the following aspects: 1) effective communication in order to be understood; 2) voluntary and conscious compliance to the project, in which everyone must be involved and be co-responsible; 3) good institutional and financial support, that is, political will and defined resources; 4) control, monitoring and evaluation; 5) an enabling environment; 6) credibility, which means that only good ideas are not enough, we must defend them with prestige, competency and legitimacy; and 7) a good theoretical framework to substantiate and sustain the project.

In this same line of thought, Vasconcellos (1995: p. 152) adds other elements that can influence the experience of the political-pedagogical project along the lines of the curriculum reform envisaged by the LDB (1996), such as: 1) self-indulgence; 2) immediacy; 3) perfectionism; 4) lack of hope and trust in the institution; 5) formalism, a project that was prepared but has no meaning, no involvement; 6) lack of the experience of common progress, as a group; 7) staff turnover; 8) the lack of conditions of time and space for reflection; and 9) lack of democratic exercise in the context of the educational institution. We understand that these elements can partially or totally affect the course PPP, if they are not improved, discussed and solved.

In this sense, HEIs must overcome the traditional curricula and adopt the theoretical and methodological frameworks of a critical and dialectic concept of education when building the pedagogical proposal (Bordignon \& Gracindo, 2004; Libâneo et al., 2003).

\subsection{The Concept of Competency and Its Application to the Educational Context}

The changes occurring in the world of work facing the new economic order greatly influence the spread of various notions of competencies according to different contexts in different historical periods. More specifically, from the eighteenth century on, the concept gained a more complex meaning, associated with a biological perspective, to reflect human beings' innate and universal willingness, giving individuals "the ideal and intrinsic ability of producing and understanding any natural language" (Dolz \& Bronckart, 2004: p. 32).

In the context of work, this idea of acquiring and developing professional competencies is corroborated in the studies of Fleury \& Fleury $(2001,2004)$ and Fleury \& Ruas $(2010)$, who understand that competency is a characteristic related to an individual's performance in a specific task, and thus different from a person's skill or natural talent, since it depends on learning throughout life. Focus in on aspects referring to subjectivity and to new labor relations (Fleury \& Fleury, 2001). In this context, competency is defined as "knowing-how-to-act, that is, knowing how to integrate, mobilize, and being able to apply a set of resources (knowledge, information, attitudes and reasoning, etc.) in a certain context, to address different problems or to perform a task" (Le Boterf, 1995: p. 14). Studies such as by Fleury \& Fleury (2001); Dolz \& Bronckart (2004) and Silva (2012), among others, contribute to thinking about curriculum changes and pedagogical processes focused on the development of competencies that instrumentalize students with the knowledge, the skills and the values that are necessary nowadays.

Pedagogical practice cannot be separated from reality, theory and practice must go together, in order to keep up with scientific and technological advances. "Teaching requires a systemic view of knowledge and not fragmented;" in this sense, academic contents must be contextualized and adapted to students' life experiences, so that theory and practice are related Fleury \& Fleury (2001); Dolz \& Bronckart (2004) and Silva (2012). In the era of globalization, of network society, new professional profiles are being required, forcing training processes to be also transformed. In this context, competency is defined as "knowing-how-to-act, that is, knowing how to integrate, mobilize, and being able to apply a set of resources (knowledge, information, attitudes and reasoning, etc.) in a certain context, to address different problems or to perform a task" (Le Boterf, 1995: p. 14).

Complying with this idea, Silva (2012) states that higher education, guided by the transmission of knowledge, has provided little significance to students, because it uses content memorization; these contents will be easily forgotten, and knowledge that was supposedly taught becomes fragmented, decontextualized and worthless to 
the learner. In this line of thought, Pereira (2013) investigated the perceptions of senior students as to the managerial competencies acquired during Accounting Sciences courses offered by HEIs in São Paulo, based on a matrix of managerial competencies drafted according to the blocks of managerial competencies subdivided in 03 main axes (organizational, social, technical-scientific) suggested by Fleury \& Fleury (2004) and Zarifian (2001). One of the study's suggestions is to create learning situations that provide students with experiences that allow access to management practices that foster the professional development of graduates about their role in the business world and in social development.

This study investigated the academic management actions facing the set of professional competencies required of Accounting Sciences course graduates. To this end, we used the competencies matrix developed by Pereira (2013: p. 47), according to the blocks of managerial competencies divided into 03 main axes suggested by Fleury \& Fleury (2001) and Zarifian (2001), which are as follows:

$1^{\text {st }}$ Axis-Organizational Competencies:
1) Troubleshooting
2) Focus on results
3) Systemic and strategic vision
4) Planning
5) Focus on the user
6) Creation and innovation
7) Ability to add value

\section{$2^{\text {nd }}$ Axis 2-Social Competencies:}

8) Exchange of information

9) Self-confidence

10) Teamwork and leadership

11) Flexibility

12) Conflict Management

13) Interpersonal relationships

14) Ethical behavior

$3^{\text {rd }}$ Axis-Technical-Professional Competencies:

15) Credibility and trust

16) Knowledge of other languages

17) Commitment and determination

18) Oral and written communication and expression

19) Investigative, critical and analytical stance

20) Knowledge of new technologies and information systems

21) Professional training and development

In this sense, the concept of professional competencies for the purpose of this research is in accordance with Fleury \& Fleury (2001: p. 34), who understand that peoples' competencies are characterized as managerial to the extent that knowledge, skills and attitudes are made available to companies, so that it is possible to mobilize and integrate resources and add value to them. We can say that, among the new competencies that are necessary to the knowledge worker, managerial competency plays a key role.

\subsection{The Accounting Sciences Course in the Context of Curriculum Reform}

The degree in Accounting and Actuarial Sciences, according to Carvalho (2010), was created in 1945, through Decree 7988, published on 22 September and signed by President Getulio Vargas. The course lasted four years; this model remains to the present day. Iudicibus \& Marion (2000) criticize the organization of courses in the accounting field, saying that there is excessive concentration on technical disciplines, restricting courses to a vision that is focused only on accounting records and which denies a broader view of the application of the accounting concepts that students learn.

The need for flexibility and change in accountants' training complies with what is proposed by the LDB (1996), which provides autonomy for HEIs to develop curricula that are more focused on the local and regional realities of each course. In Brazil, the hallmark of these changes can be seen mainly after the implementation of Law 9.394/96- Law of Directives and Bases of National Education (LDB). With a view to the better adaptation 
of these policies to reality, these determinations are being adjusted, mainly by ministerial orders and post-LDB regulatory decrees.

Brazil Resolution CNE/CES 10 (2004) established the DCN for Accounting Sciences undergraduate courses, determining that each HEI should establish, as well as curricular organization, described by the PPP, curriculum components, evaluation systems, supervised curriculum internship, further activities, the Final Course Project (Trabalho de Conclusão de Curso-TCC) and the academic regime of supply. The guidelines indicate a more managerial training for accountants, something that can be achieved by making the curriculum flexible with a view to building the PPP.

It is worth clarifying that this study is based on a concept related to culture, explained by Gimeno Sacristán (2000: p. 48) as "a determination of action and practice, just as the valuations on what is appropriate culture." Accordingly, Gimeno Sacristán (1998: p. 81) also reminds us that "education not only serves to reproduce realities, but to rebuild the tradition that makes up the culture, or the cultures, and to achieve an ideal of life, which is the challenge of the future." In this logic, the guidelines mean review of undergraduate courses, and thus of accountants' education, so they can make a contribution in the process of generating value for organizations. According to Carvalho (2010) education should be a planned action, and the curriculum needs to be flexible and dynamic.

\section{Studies on the Set of Competencies of Accountants}

The world of work, marked by instability, uncertainty, and fierce competition determines a new economic and social order, a fact that has implications for education and creates the need for new competencies to face the challenges of the contemporary world. Authors such as Cornachione Jr. (2004) and Ravenscroft \& Rebele (2008) discuss the training of the accounting professional, emphasizing the need to revise the existing pedagogical proposals, which, although they seek to comply with what is proposed by the LDB (1996), in practice curricula remain rigid and inflexible; they highlight that scientific training and as to values toward a managerial profile for decision-making should supplant the excessively technical professional, whose main concern is to perform tasks and meet the requirements of tax authorities.

Internationally, Ott et al. (2011) mention specialized bodies such as the International Federation of Accountants (IFAC) and the International Education Standards (IES), which suggest contents related to the knowledge, skills and values such as ethics and sustainability of organizations that students of HEIs should be part of the training of future accountants. Regarding graduates' from Accounting Sciences courses, Lombardi \& Nodari (2008) emphasize that current accountants should be professionals concerned with the management of information for decision-making and, therefore, a "controller." Thus, they should be participative, focused not only on financial performance, but involved with the social and the environmental, as part of the strategic levels and decision-making in the company.

As to the managerial skills of Brazilian accountants, the study of Cardoso (2006) sought to define the competencies of accountants in Brazil, in later studies, Cardoso, Riccio, \& Albuquerque (2009) and Cardoso, Mendonça Neto, \& Oyadomari (2010) compared what is valued in the training of accountants in Brazil with what is contained in the documents of international organizations (IFAC/IAESB). The results showed that there are points of similarity, however, the differences are related to aspects involving training that is more technical than managerial in Brazilian accountants when compared to professionals from other countries.

The findings were corroborated by the study of Marin, Lima, \& Casa Nova (2011), who investigated the opinion of students graduating from a public HEI in São Paulo as to the technical knowledge and the challenges of the accounting profession. The study found that, in general, the students excelled as to theoretical knowledge and proactive approach, however, presented deficiencies in practical knowledge, foreign languages and leadership. Similar studies have been developed by foreign research such as that by Byrne \& Flood (2008), Jones (2010), Swain \& Olsen (2012) and others who investigated Accounting Sciences students and the development of professional competencies in countries such as Australia, New Zealand, the USA and Canada.

Among the results we highlight the competency models that are associated with the organizational dimension, such as creativity and innovation, and the social dimension, such as cognitive skills, interpersonal relationships, and technical-professional competencies, which suggest development along the lines of management.

\section{Research Methodology}

Considering that the aim of this study was to find out about academic management actions facing the set of pro- 
fessional competencies needed by graduates from an Accounting Sciences course, we understood that qualitative descriptive research would be the most suitable option. The study was limited to the academic management of an Accounting Sciences course offered by a HEI in the city of São Paulo, which was chosen because it received grade 05 in ENADE. The choice of manager resulted from his academic background in education $(\mathrm{PhD})$ and accounting (undergraduate and graduate). It is also due to the fact that he is course coordinator of the researched course since 2007, and has experienced the national curriculum changes and their implementation in the course.

Data collection took place through interviews made up of the following parts: 1) the first part was based on the study of Scatola (2013). The goal was to raise a profile of the researched person and consisted of questions such as: education; professional experience; practice of research at the university; training in the field of education and school management; and desired profile of students graduating from the course designed in the PPP, in questions 01-14;

2) In the second part we used a set of 21 professional competencies created by Pereira (2013). The goal was to identify the level of importance and perceptions of the coordinator as to the set of competencies deemed necessary to accountants' performance. Thus, we presented a matrix of professional competencies with a Likert scale, and levels of importance as follows: a) Not important (NI); b) Partially important (PI); c) Important (I); d) Very important (VI); e) Totally important (TI). The 21 competencies were divided into axes of competencies, namely: i) organizational; ii) social; iii) technical-professional. This part was developed based on the following question: What is the degree of importance of these competencies to accountants' performances?

3) The third part aimed at identifying academic management actions facing the set of professional competencies needed by graduates. Thus, we presented the same matrix with 21 competencies used in the first part of the interview, and the following question was made: In what way have the competencies considered important to the work of accountants been developed and improved in the course?

For the interview, we presented the research and requested that interviewees sign the term of free, informed consent, in order to maintain their integrity.

\section{Results and Discussions}

The results follow the interview guide and are presented as topics and sub topics such as: 1) a brief profile of the coordinator of the investigated course; 2) set of competencies required to graduating from Accounting Sciences; 3) academic management actions facing the desired profile of students graduating from Accounting Sciences.

\subsection{A Brief Profile of the Research Collaborator}

The investigated coordinator is 38 years old, married, has been involved with course management since 2007, teaches in the course, conducts research, and, specifically as to management activities, has also been graduate dean since 2014. According to him, the opportunity to act as coordinator in this HEI resulted from "personal history with the institution, and also experience; in all, thirteen years of coordination, and here alone, nine years" (interview data, 2015). He has a bachelor's and a master's degree in accounting and a doctorate in education. As for education management, he says he has specific training in organizations, having worked "in industry, in management positions, and attended some short courses in higher education management" (interview data, 2015). He says he has full autonomy to coordinate the course and implement the necessary curricular changes in view of the desired profile of the course graduate and future accounting professional. This data corroborates Libâneo (2001), who says that the knowledge, beliefs and attitudes of academic management impact how it manages the PPP and that this should be "a critical and reflective intellectual, a qualified participant in school management."

\subsection{Set of Competencies Required to Graduating from Accounting Sciences}

As to the importance attributed to each of the competencies required for accountants' performances, the data shows that the coordinator is aware of the need to address training according to competencies, and to connect this training to the profession, as reported below:

"Yes, as coordinator of the course, all subjects that are in the curriculum matrix I see as of maximum importance, each in its specificity (...). So all of them with grade 5 (five) in the degree of importance of competencies, since all the disciplines develop competencies in their fields, but some are more basic, and other 
are more technical" (interview data, 2015).

As it turns out, the coordinator believes that the curricular-pedagogical proposal established in the course is aligned with the matrix of professional competencies required for accountants' performances, and in them the idea that the concept of competency in professional education is associated with both skills and values and knowledge.

This perspective is confirmed in Table 1, which shows what the pedagogical ideals of the coordinator are as to the importance of competencies in the training of course graduates. When asked about the matrix of professional competencies, with a Likert scale, and levels of importance as follows: 1) Not important (NI); 2) Partially important $(P I)$; 3) important $(I)$; 4) Very important $(V I)$; 5) Totally important $(T I)$.

These data reveal an intention of professional training which considers, beyond mere technical knowledge, scientific and attitudinal knowledge, complying with authors such as Libâneo (2001); Vieira \& Vieira (2004); Barbalho (2007), who advocate training according to competencies, as opposed to technical training and "hyperspecialization" which makes it difficult to "understand the complexity of the present world" (Siqueira, 2003: p. 4), and denies the competency required by the labor market.

Table 1. Axes and matrix of professional competencies.

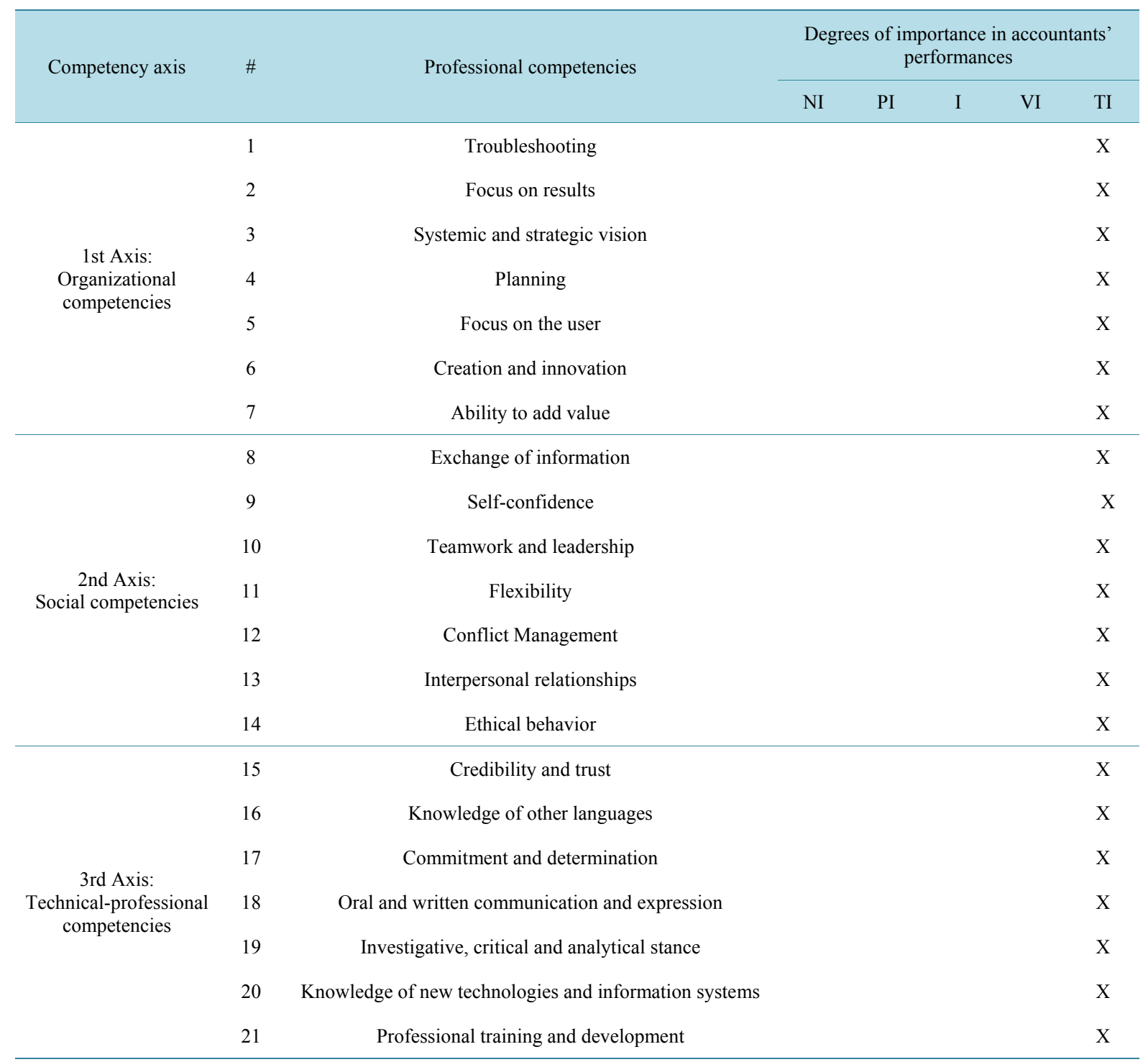

Source: Adapted from Pereira (2013). 


\subsection{Academic Management Actions Facing the Set of Professional Competencies Needed by Graduates from Accounting Sciences Courses}

As to the actions aimed at improving the competencies considered important to the training of Accounting Sciences graduates, the coordinator considered the collective construction of the course Pedagogic Political Project of the course and the organization of "structuring teaching core" or "hard core" (interview data, 2015) of the course as the core of the whole process, in view of curriculum management. This activity requires collective work, with regard to the formation of a collegiate. This specific aspect revealed the coordinator's management profile. Decentralized and democratic decision-making leads him to delegate tasks and responsibilities to teachers who are specialists in each field of knowledge, as well as the responsibility to think and assist in decision-making. This demonstrates that there is a dialogue between teachers seeking course improvement and adequacy between the demands of training and the profession, as follows:

All the time, there are disciplines that are applied throughout the course, but implicitly rather than explicit; this is the case of the ethics discipline, it is only taught to students in the 5th semester, but it is implicit throughout the course, and through all teachers and other disciplines less often, not to mention the discipline of accounting, which is enhanced throughout the course explicitly, and is structured throughout the whole course; it begins basic, intermediate, advanced and passes to technical, such as tax, international and so on (Interview data, 2015).

These results indicate curricular flexibility, planning and evaluation of actions, by the academic management of the investigated course. Curricular dynamism shows how the course is designed in view of the desired profile of graduates; these are attitudes, beliefs, values and actions that permeate management, which reveal the school culture present in the investigated HEI.

Specifically, as to actions aimed at the development and improvement of each of the competencies considered important to the training of Accounting Sciences course graduate, we obtained a detailed account from the coordinator; we will present them below.

Table 2 reports reveal a democratic profile and decentralized management, as well as the use of strategies that allow the involvement of everyone in curricular decision-making. We notice the value of institutional autonomy, a fact that allows the exercise of decentralized management and the exchange of experiences in decision-making, complying with what Veiga (1996); Gadotti (2000) say when they state that a project is not built without political direction, a north, a direction. Therefore, every pedagogical project is also political.

\section{Possible Conclusion}

This research aimed at understanding academic management actions facing the set of competencies graduates from an Accounting Sciences course need. We found that the set of graduates' professional competencies linked to the organizational, technical-professional and social blocks require academic management competencies such as: 1) democratic management and the collective construction of a pedagogical-political project for the course; 2) a systemic vision and the creation a place for the institutionalization of joint actions; 3) creation of places for dialogue (schedule of meetings and collegiates) and the interaction between fields/disciplines (structural teaching core); 4) knowing how to manage conflicts and solve problems; 5) human resource management; 6) practice of ethics in teaching and in the profession; 7) strategic planning and control of actions; 8) trust and confidence; 9) curricular flexibility and dynamism; 10) professional self-development; 11) course change and innovation; 12) exercising leadership.

These results indicate that the democratic management revealed in the academic management's requires the mobilization of managerial and teaching competencies optimized through the creation of participatory instances and discussion environments such as educational meetings, gatherings and an agenda for the resolution of issues concerning the collective construction of the curricular-pedagogical project.

Thus, we can conclude that the academic management actions are aligned with the set of competencies needed by graduates of an Accounting Sciences course as a basic condition for achieving the desired results and the quality of education that the HEI offers. We can say, in this sense that democratic management contributes to closer ties between what the world of work requires as to "real-world practice" and what the academic world values. This is the challenge of academic management as to the application of the current education legislation in view of the profile of the desired accountant in the contemporary world. 
Table 2. Academic management actions facing the set of competencies necessary to graduating from an Accounting Sciences course.

\begin{tabular}{|c|c|}
\hline Academic management actions & Interview data \\
\hline $\begin{array}{l}\text { Democratic management and } \\
\text { collective construction of the } \\
\text { pedagogical-curricular } \\
\text { proposal }\end{array}$ & $\begin{array}{l}\text { "I think that quality education is having the commitment of all spheres of management, of } \\
\text { coordinators, of teachers and of students." [...] "Always based on the supposition that you have gooc } \\
\text { teachers. So if you prove to be an organized coordinator and your team of teachers is organized, I } \\
\text { mean organized in the sense of having a perfect, directed PPP, of having a curricular matrix that } \\
\text { everyone knows and of which everyone participates, that everyone talks about, having teachers that } \\
\text { are dedicated, who participate in meetings, who give their opinions, who are present in classrooms, } \\
\text { who are committed, then if this organization is good I think management becomes easy." }\end{array}$ \\
\hline $\begin{array}{l}\text { Systemic vision, } \\
\text { curricular flexibility, } \\
\text { strategic planning and } \\
\text { evaluation of action }\end{array}$ & $\begin{array}{l}\text { "This institution has always been at the forefront, I will blow my own trumpet, just to give an } \\
\text { example, I have been teaching here since } 2002, \text { and since then I have been an international } \\
\text { accounting professor, before Brazil adopted the international rules this institution already had this } \\
\text { discipline in its curricular matrix, when the changes came, we adjusted the disciples rather than } \\
\text { structurally adjust the PPP, because it was already focused on what was coming." } \\
\text { "(...) I have been in this institution since I graduated, the student profile has changed. This } \\
\text { institution is considered an open door, a door to change, when students enter they think, I want a } \\
\text { profession and I want to be recognized, so this is the right place." }\end{array}$ \\
\hline
\end{tabular}

Creation of a place for dialogue, for conflict management and troubleshooting

Human resource management

Experience and technical competence

Ethical stance and practices in teaching and in the accounting profession

Working in a team, being critical, reflexive, have planning and control of actions carried out

Self-training

Having projects that aim at course change and innovation

Being more of a leader than a manager
"The infrastructure problems do not worry me, my management is focused on content, on curricular organization and obviously it is the coordinator's job to see to day to day problems, student complaints, teacher complaints, we are a kind of call center". (...). "We offer something different here, we sit down with students and meet their demands."

“(...) He has to know about management, he has to manage conflicts, we have many teachers, many students, teachers with egos and different personalities, so you have to know how to deal with people, management as a whole, management with leadership (...)."

"Because of the history I have with the institution and, also, because of experience. All in all, I have thirteen years of management experience, here alone it's been nine years. (...) I don't have any classical specific training in school management, but I worked in industry in management positions and took some short management courses."(...) "I never thought I'd be a coordinator, only a teacher, it wasn't something I'd prepared myself for, I worked in companies and held management positions, as usually occurs in the Accounting field."

"I finished graduation one year, in the next I was already teaching, my student memories were very fresh, so I felt that my teachers weren't just my teachers, they were examples, so once again this bureaucratic part of the teacher being on time, I think that's cool, if the teacher is well-dressed I think that's cool, if the teacher is a nice guy I think it's cool, if the teacher is rude I don't like it, so, you see, (...)."

"So if you prove to be an organized coordinator and your team of teachers is organized, I mean organized in the sense of having a perfect, directed PPP, of having a curricular matrix that everyone knows and of which everyone participates, that everyone talks about, having teachers that are dedicated, who participate in meetings, who give their opinions, who are present in classrooms, who are committed, then if this organization is good I think management becomes easy."

"I have a master's degree in Accounting Sciences. I have a PhD in Education mainly to better understand the course PPP."

“Contextualizing, the definition of innovation is to create something new, that doesn't yet exist, accounting follows and answers creativity, the business world invents and we account for it, now thinking about the accounting professional, if he manages to innovate that is a plus."

"He has to know about management, he has to manage conflicts, we have many teachers, many students, teachers with egos and different personalities, so you have to know how to deal with people, management as a whole, management with leadership, in sum he has to have a technical vision, knowledge of education, knowledge of management (...)."

Source: The authors. 
As further research, we suggest to expand the database to include reviews from other coordinators, presenting different profiles and contexts in the provision of Accounting Sciences courses. In sum, curriculum management guided by the paradigm of complexity and of systemic thinking requires a break with the epistemology guided by linear and technical thought. This requires a new attitude from HEI and course managers, who should review the curriculum theory and its consequent methodology to better promote student learning.

\section{References}

André, M. E. D. (2010). O Projeto Pedagógico como Suporte para Novas Formas de Avaliação. São Paulo: FEUSP.

Barbalho, M. G. C. (2007). Higher Education: Expansion Trends and Strategies in Latin America and Brazil. In Cabral Neto, A. et al. (Eds.), Points and Counterpoints of Educational Policy: A Contextualized Reading of Government Initiatives (pp. 13-50). Brasília: Líber.

Bordignon, G., \& Gracindo, R. V. (2004). Education Management: The Municipality and School. In N. S. C. Ferreira, \& Aguiar, M. A. S. (Eds.), Education Management: Deadlocks, Perspectives and Commitments (4th ed., pp. 147-176). São Paulo: Cortez.

Brazil Resolution CNE/CES 10 (2004). Establishing National Curriculum Guidelines for Undergraduate Degrees in Accounting, and Other Measures.

Brazil Law \#9394 (1996) Establishing Guidelines and Bases for National Education. Brasília: Congresso Nacional. http://portal.mec.gov.br/seed/arquivos/pdf/tvescola/leis/lein9394.pdf

Byrne, M., \& Flood, B. (2008). Examining the Relationships among Background Variables and Academic Performance of First Year Accounting Students at an Irish University. Journal of Accounting Education, 26, 202-212. http://dx.doi.org/10.1016/j.jaccedu.2009.02.001

Cardoso, R. L. (2006). Accountant Competencies: An Empirical Study. Thesis (Doctorate in Controllership and Accounting)-School of Economics, Administration and Accounting, São Paulo: University of São Paulo.

Cardoso, R. L., Riccio, E. L., \& Albuquerque, L. G. (2009). Accountant Competencies: Studying the Existence of an Interdependent Structure. USP Administration Journal, 44, 365-379.

Cardoso, R. L.; Mendonça Neto, O. R.; \& Oyadomari, J. C. (2010.) International studies concerning competencies and knowledge, skills and attitudes of the Brazilian management accountant: analysis and reflections. Brazilian Business Review, Vitória-ES, v. 7, n. 3, p. 91-113, Sept./Dec. http://dx.doi.org/10.15728/bbr.2010.7.3.5

Carvalho, R. F. (2010). Accounting Curriculum: Challenges for the Adoption of the New Brazilian Accounting Model. 2010.145 f. Thesis (Doctorate in Education), São Paulo: PUCSP.

Cornachione Jr., E. (2004). Education Technology and Accountancy Courses: Virtual Collaborative Models. Thesis (Free Teaching), São Paulo: School of Economics, Administration and Accounting, University of São Paulo.

Cosenza, J. P. (2001). Prospects for the Accounting Profession in the Globalized World: A State Based on the Brazilian Experience. RBC-Brazilian Accounting Journal, 130, 35-51.

Deffune, D., \& Depresbiteris, L. (2002). Competencies, Abilities and Professional Education Curricula: Chronicles and Reflections (2nd ed.). São Paulo: Ed. SENAC.

Dolz, J., \& Bronckart, J. P. (2004). The Notion of Competence: What Is Its Relevance to the Study of Learning the Language of Actions? In J. Dolz, \& E. Ollagnier (Eds.), The Enigma of Competence in Education (pp. 29-46). Porto Alegre: Artmed.

Fleury, M. T. L., \& Ruas, R. (2010). Competencies, Concepts, Methods and Experiences (pp. 31-50). São Paulo: Atlas.

Fleury, A., \& Fleury, M. T. L. (2004). Business Strategies and Training Competencies: A Kaleidoscopic Puzzle of Brazilian Industry (3rd ed.). São Paulo: Atlas.

Fleury; M. T. L., \& Fleury, A. (2001). Building the Competence Concept. São Paulo. http://www.scielo.br/pdf/rac/v5nspe/v5nspea10.pdf

Gadotti, M., \& Romão, J. E. (Orgs.) (2000). School Autonomy: Principles and Proposals. São Paulo: Cortez, Paulo Freire Institute. (Citizen School Guide)

Gimeno Sacristán, J. (1998) Approach to the Concept of Curriculum. In J. Gimeno Sacristán (Ed.), The Curriculum: A Reflection on Practice (Chap. 1, pp. 13-87). Porto Alegre: ArtMed.

Gimeno Sacristán, J. (2000). The Curriculum: Teaching Contents or a Practical Analysis. In J. Gimeno Sacristán, \& Pérez Gómez, A. I. (Eds.), Understanding and Transforming Teaching (4th ed., Chap. 6, pp. 119-148). Porto Alegre: ArtMed.

International Federation of Accountants (IFAC) (2012). Handbook of International Education Pronouncements. 2012 Edition, New York. http://www.ifac.org

Iudicibus, S., \& Marion, J. C. (2000). Accounting Course for Non-Accountants. São Paulo: Atlas. 
Jones, A. (2010). Generic Attributes in Accounting: The Significance of the Disciplinary Context. Accounting Education, 19 , 5-21. http://search.proquest.com/docview/224833839? accountid=34586 http://dx.doi.org/10.1080/09639280902875523

Le Boterf, G. (1995). On Competence: Essay on a Strange Attractor. Paris: Éditions d'Organisation.

Libâneo, J. C. (2001). School Organization and Management: Theory and Practice. Goiânia: Alternativa.

Libâneo, J. C. et al. (2003). School Education: Policy, Structure and Organization. São Paulo: Cortez.

Lombardi, M. F. S., \& Nodari, L. D. T. (2008). Skills Acquired in Undergraduate Degree in Business Administration from the Perspective of Graduating Students. RACE/UNOESC, 7, 117-130.

Marin, T. I. S., Lima, S. J., \& Casa Nova, S. P. C. (2011). Accountant Training-What the Market Wants Is What It Has? Case Study on the Professional Profile of Students in Accounting Sciences. USP Controllership and Accounting Congress. Annals. São Paulo: FEA-USP.

Masetto, M. T. (2003). Pedagogical Competence of the University Professor. São Paulo: Summus.

Ott, E. et al. (2011). Relevance of Knowledge, Skills and Instructional Methods from the Perspective of Students and Professionals in the Field of Accounting: International Comparative Study. In: V ANPCONT Congress 2011, Vitória/ES, Annals, Accounting and Performance in the New Development Cycle.

Pereira, M. S. A. (2013). Perceptions of Graduating Students on Managerial Skills Acquired in the Accountancy Course Offered by a HEI in São Paulo. 114 f. Essay (Master of Science in Accounting), São Paulo: FECAP.

Ravenscroft, S. P., \& Rebele, J. E. (2008). The Importance of Accounting Education Research. Journal of Accounting Education, 26, 180-187. http://dx.doi.org/10.1016/j.jaccedu.2009.02.002

Scatola, E. S. P. (2013). Curriculum Reform and the Challenges of Coordinating an Accountancy Course on the Management of the Political Pedagogical Project. Dissertation (Masters in Ciências Contábeis), São Paulo: FECAP.

Silva, A. C. R. (2012) Education by Competencies. São Paulo: Paço Editorial.

Siqueira, H. S. G. (2003). Interdisciplinary Training: Social and Political Requirement for a Networked World. In: State Symposium of Home Economics, $7^{\text {a }}$ ed. 2003, Francisco Beltrão, PR, Electronic Proceedings, Francisco Beltrão, PR: UNIOESTE, Acesso em 25 Janeiro 2016. http://www.angelfire.com/sk/holgonsi/mundorede.html

Slomski, V. G. (2007). Knowledge and Skills of University Teachers: Contributions to the Study of Brazilian Accounting Teachers Teaching Practices. Journal of Accounting and Organizations, 1, 86-106.

Slomski, V. G. et al. (2010). Curricular Competence Approach: A Vision by Coordinators of Bahia Undergraduate Courses in Accounting. ReAC-Journal of Management and Accounting, 2, 4-14.

Souza, J. S. (1998). The Capital Crisis and the Redefinition of the Brazilian Educational Policy in the 90s. FAEEBA Journal, 10, 43-72.

Swain, M. R., \& Olsen, K. J. (2012). From Student to Accounting Professional: A Longitudinal Study of the Filtering Process. Issues in Accounting Education, 27, 17-52. http://dx.doi.org/10.2308/iace-50076

Vasconcellos, C. S. (1995). Planning: Teaching-Learning Plan and Educational Project. São Paulo: Libertad.

Veiga, I. P. A., \& Fonseca, M. (Orgs.) (2001). The Dimensions of the Political-Pedagogical Project (2nd ed.). Campinas: Papirus.

Veiga, I. P. A. (Org.) (1996). Political-Pedagogical Project: A Possible Construction (2nd ed.). Campinas: Papirus.

Vieira, E., \& Vieira, M. (2004). Bureaucratic Functionality in Federal Universities. Journal of Contemporary Administration, 8, 181-200.

Zarifian, P. (2001). Competence Objective: For a New Logic. São Paulo: Atlas. 